\title{
Justice for Magdalenes: From Advocacy Support Group to Human Rights Issues
}

Nathalie Sebbane

\section{(2) OpenEdition Journals}

Electronic version

URL: http://journals.openedition.org/etudesirlandaises/4544

DOI: $10.4000 /$ etudesirlandaises. 4544

ISSN: 2259-8863

Publisher

Presses universitaires de Rennes

\section{Printed version}

Date of publication: 30 June 2015

Number of pages: $185-197$

ISBN: 978-2-7535-4082-8

ISSN: 0183-973X

Electronic reference

Nathalie Sebbane, « Justice for Magdalenes: From Advocacy Support Group to Human Rights

Issues », Études irlandaises [Online], 40-1 | 2015, Online since 30 June 2017, connection on 26 April

2019. URL : http://journals.openedition.org/etudesirlandaises/4544 ; DOI : 10.4000/

etudesirlandaises.4544 


\title{
Justice for Magdalenes: From Advocacy Support Group to Human Rights Issues
}

\author{
Nathalie Sebbane \\ Université Sorbonne Nouvelle-Paris 3
}

\section{Résumé}

On the $17^{\text {th }}$ of May 2013, Justice for Magdalenes (JFM), the survivor advocacy group, announced the end of its political campaign, begun in June 2009. It contributed to exposing the Irish State and the religious congregations that ran the laundries, and forcing them to take responsibility. Through sustained and relentless activism and engaging with the political forces of the nation, the religious orders and national and international human rights institutions, JFM managed to obtain a formal apology on behalf on the Irish State by An Taoiseach, Enda Kenny, and a compensation and redress scheme for former residents of the institutions. This paper proposes to examine the different aspects of JFM's campaign, its achievements and continuous commitment.

Keywords: Magdalen Laundries, Irish State (Republic of Ireland), activism, justice, human rights

\section{Abstract}

Le 17 mai 2013, Justice for the Magdalenes (JFM), un groupe de soutien aux anciennes résidentes des institutions, fondé en 2009, annonçait publiquement qu'il mettait fin à sa campagne politique, inaugurée quatre ans plus tôt. Le groupe était en effet parvenu, grâce à une campagne soutenue en direction des forces politiques irlandaises, mais également des congrégations religieuses et des instances internationales de défense de droits de l'homme, à obtenir des excuses publiques du Premier ministre, Enda Kenny, au nom de l'État irlandais, ainsi qu'un plan de compensation financière pour les anciennes résidentes. Cet article se propose de présenter les différents aspects de la campagne de $J F M$, les résultats obtenus et la suite des activités du groupe.

Mots clés: Magdalen Laundries, État (République d'Irlande), militantisme, justice, droits de l'homme

There is no single or simple story of the Magdalen Laundries.

(Dr. Martin McAleese)

\section{圈 Context}

After completing my dissertation on the 1986 divorce referendum and my Research Master's Degree on the 1983 abortion referendum under his supervi- 
sion, I started my PhD with Prof. Paul Brennan back in 2003. My original plan was to carry out my research on the Magdalene Laundries and Paul Brennan was very enthusiastic about the project. He encouraged me to pursue the idea and I launched myself into a quest for sources.

However, after about two years of intense researching, I came to the conclusion that I would not be able to carry out my initial plan for lack of primary sources. Ireland was working through numerous scandals smearing the reputation of the Catholic Church at the time, and the religious authorities were more reluctant than ever to give access to material and archives.

It was a very frustrating experience because I could feel, and Paul was supporting me in that line, that there was something worth digging out and that somehow, the issue would come up sooner or later and would become one of Ireland's darkest historical episode.

A few Irish and British historians ${ }^{1}$ had carried out some research on the issue in the late 1980s and early 1990s, so I got in touch with them and they informed me that all access to primary sources had been shut down in the light of the recent revelations and that I would be well-advised to try and find another angle for my PhD.

Paul's premature death and my subsequent decision to follow on with Prof. Catherine Maignant precipitated events and with the help of my new supervisor, I reoriented my research and did my $\mathrm{PhD}$ thesis on unmarried mothers in Ireland from the mid 19th century up to the enactment of the 1937 Constitution $^{2}$. It allowed me to devote a considerable part of my work to Magdalene Laundries, using earlier material, which had not been censored by the religious orders.

Since then, I have continuously followed the issue and recently, things have moved fast. Last year, I published a paper on the issue of human rights regarding the institutions and it seemed to me relevant, in this particular issue of Etudes Irlandaises, to follow on and write a paper on the latest developments.

On the 17th of May 2013, Justice for Magdalenes (JFM), the survivor advocacy group, announced the end of its political campaign, begun in June 2009. As outlined in the "Public Notice" posted on the group's website, the political campaign had twin objectives, namely:

(i) to bring about an official apology from the Irish State, and

(ii) the establishment of a compensation scheme for all Magdalene survivors ${ }^{3}$.

1. Notably Maria Luddy and Frances Finnegan, and, later on, James Smith.

2. Perceptions et représentations de mères célibataires en Irlande de 1838 à 1937. Doctoral dissertation submitted in December 2008 under the supervision of Prof. Catherine Maignant, University Charles de Gaulle-Lille 3.

3. Although most people are now familiar with the issue of the Magdalene Laudries, a brief historical perspective is necessary. Originally termed Magdalene Asylums, the first in Ireland was opened in Dublin in 1765, for Protestant girls. The first Catholic home was founded in Cork in 1809. Envisaged as short-term refuges for "fallen women", they became long-term institutions and penitents were required to work, mostly in laundries on 
And, as the "Public Notice" explains, "[o]nce Justice for Magdalenes achieves these objectives, the door will be open to every survivor and/or her family members and/or other groups representing Magdalene survivors to pursue their own claim for redress $s^{4}$." JFM's announcement therefore raised a couple of interesting issues regarding how and why the group started, its composition and membership, and more interestingly, what their campaign had been about, how it was organized, what it had led to and why it was coming to an end.

After briefly presenting the origins of the group, this paper will focus on the three aspects of its campaigning: the political, religious and human rights issues. It will show that, thanks to its unrelenting determination, JFM managed to achieve considerable progress in moving the debate surrounding the Magdalene Laundries into the political sphere, giving it national and international visibility. By forcing the Irish State to admit responsibility for the inhuman treatment that many inmates of the institutions had to go through, the group has opened the way for other wrongs to be redressed.

\section{Origins of Justice For Magdalenes}

In 1993, the Sisters of Our Lady of Refuge decided to sell a property they held in Drumcondra, which used to be the site of a convent laundry. St Mary's Asylum (also known as St Mary's Penitentiary or Magdalene Home) had been in operation since the late 1850s and had closed its doors in 1991. It was the largest institution of its kind in Ireland. A burial ground was located to the west of the Asylum building. In 1993, when the Sisters decided to sell off some of the land, they applied to the Department of the Environment for permission to exhume the remains of 133 women from unmarked graves. When the bodies were exhumed, on 23rd August 1993, a further 22 remains were discovered and the Sisters applied to the Department for an additional exhumation order. It later transpired that the Sisters had not been able to produce death certificates for 22 women on the exhumation

the premises. Magdalene Laundries were institutions operated by female religious congregations. The resident women, called "penitents", were unmarried mothers, "wayward girls", as was said at the time, girls who had run into minor troubles, or children transferred from Industrial Schools. Their identities were changed, they were forced to work long days in very harsh conditions and were not paid. They were condemned to a life of penitence and silence, often suffering psychological and physical abuse as well. They could not leave the institution without being signed out. Many residents remained to live, work, and ultimately died, behind convent walls. After 1922, Irish Magdalene Laundries were operated by 4 religious orders :The Sisters of Mercy (Galway and Dun Laoghaire), The Sisters of Our Lady of Charity (Drumcondra and Sean MacDermott Street, Dublin), the Sisters of Charity (Donnybrook and Cork), and the (Good Shepherd Sisters (Limerick, Cork, Waterford and New Ross). All four Congregations are members of CORI and also managed state residential institutions. The nuns do not release records for women entering the laundries after 1 January 1900. The last Magdalene Laundry in Ireland ceased operating as a commercial laundry on 25 October 1996.

4. [http://www.magdalenelaundries.com/press_releases.htm], web page viewed on July 8, 2014. 
orders and that fictitious names had been given. The remains of 155 women were eventually recovered, cremated and then reinterred at Glasnevin Cemetery.

In the public outcry that followed, revelations began to emerge about the decades of cruelty and abuse that had taken place at the Asylum and others like it. In 1993, upon the discovery of the 133 graves at High Park Convent, a small group of women formed the Magdalen Memorial Committee (MMC) to pay tribute to the women whose existence had been hidden and silenced, in life and death.

When the Residential Institutions Redress Act ${ }^{5}$ was passed in 2002, which addressed institutional abuse of children in Industrial Schools, the MMC disbanded. However, several women decided to take the work of the MMC a step further and founded Justice for the Magdalenes (JFM) in 2004.

The coordinating committee comprises people whose lives have been directly affected by Magdalene Laundries and the adoption rights issue (Mari T. Steed, Claire McGettick and Angela Murphy are all adoptees). The advisory committee includes academics and researchers but also authors and politicians. JFM then expanded their mission to include legislative and reform work to ensure that survivors of Ireland's Magdalene Laundries would not be forgotten, despite the State's and the religious orders' tacit refusal to acknowledge or apologise to them.

The group's campaign was actually three-fold: it targeted the Dáil, politicians and the government; it tried to engage with members of the Conference of Religious of Ireland (CORI) and religious congregations and, above all, it turned the issue of the Magdalen Laundries into a human rights issue, by appealing to the IHRC (Irish Human Rights Commission) and finally to the UNCAT (United Nations Committee Against Torture).

As mentioned previously, JFM's aim was to try and establish state complicity in the abuse suffered by inmates of the Magdalene Laundries. Therefore, the whole political campaign started when the Magdalene Laundries were excluded from the Residential Institutions Redress Act ${ }^{6}$.

In reality, JFM found that there were different pathways into the laundries. Apart from "traditional" non-state actors, there were also a certain number of actual state referrals to the laundries. Also, a certain number of court referrals have been identified, notably for children and women with disabilities. Few of them entered on their free will.

5. [http://www.irishstatutebook.ie/2002/en/act/pub/0013/index.html].

6. In 2002, the Residential Institutions Redress Act was passed, which addressed abuse and neglect suffered by thousands of Irish children in industrial schools and other state-licensed residential institutions. Unfortunately, Magdalene survivors were omitted from this group simply because the Irish State claimed that the laundries were private-run institutions and that the State had no involvement in the way the women were admitted or in the financing and management of the institutions. 
That is the reason why JFM contended that the Irish State needed to acknowledge its role in placing women in the laundries and its responsibility for their abuse in them. It took an incredible amount of time, energy and dedication for a small group of people to put enormous pressure on the Irish government and parliament in order to obtain public acknowledgment of responsibility and proper measures to ensure that the issues of compensation and redress would be addressed.

\section{图 JFM's national political campaign: evolution and perspectives}

This part will, for obvious reasons, focus on the main dates and landmarks. It will shed some light on the evolution of the group, its focus and methods, and the official responses it received over the four years of its campaign. On July 29, 2009, the JFM committee called on Government to provide redress for Magdalene survivors after the publication of the Report of the commission to Inquire into Child Abuse. ${ }^{7}$ The scheme was to include:

- A Trust Fund in lieu of wages not paid to women who worked there. Religious should contribute to it;

- Pensions for survivors;

- Housing assistance;

- Medical care;

- Availability of records for relatives and children ${ }^{8}$.

The Government rejected the request in September 2009. A few weeks later (October 7, 2009), the Minister for Education, Batt O'Keefe, rejected JFM's demand for a redress scheme after a debate in the Dáil on the previous day', arguing that the state was only liable for children transferred from residential institution, that the laundries were privately owned and operated, and the state did not refer individuals nor was it complicit in referring individuals to the laundries $^{10}$. In the opinion of the State, there was thus a difference between persons taken into the laundries privately and persons who were resident in State-run institutions. However, JFM had demonstrated that it was not the case. Therefore, the members sent numerous petitions and letters to TDs and ministers, asking for meetings and putting increasing pressure on official bodies.

7. [http://www.childabusecommission.com].

8. [http://www.magdalenelaundries.com/press_releases.htm], page viewed July 12, 2014.

9. "As the Deputies will be aware, the Magdalen Laundries were privately owned and operated establishments which did not come within the responsibility of the State and were not subject to State regulation or supervision."

10. [http://www.magdalenelaundries.com/okeefe_response.pdf]. 
Eventually, on December 15, 2009, The Department of Justice contradicted the Minister for Education's statement that the State "did not refer individuals nor was it complicit in referring individuals to Ireland's Magdalene Laundries". In a statement released by JFM, the group details a meeting with Mr. James Martin, Assistant Secretary of the Department of Justice, during which he "stated unequivocally that after the passage of the Criminal Justice Act, 1960, the Department of Justice placed women "On Remand" at the Sean McDermott Street Magdalene Laundry (also known as the Gloucester Street laundry) and paid a capitation grant for every woman so-referred" and that "women were routinely referred to various Magdalene Asylums via the Irish court system, in an arrangement entered into by members of the judiciary and the four religious congregations operating Magdalene Laundries in the Irish State ${ }^{11}$ ". This was JFM's first landmark victory and it encouraged the group to increase its pressure.

An All-Party ad hoc committee was subsequently formed in the Dáil to address the issue of redress. After hearing presentations from members of JFM, notably James Smith, the TDs and Senators in attendance all agreed that the issue of the Magdalene Laundries could not be ignored and elected to come together as an allparty committee in order to address the matter and would call for a parliamentary debate on the issue in January 2010. M. O'Keefe eventually admitted state responsibility on January 31, 2010 ${ }^{12}$. JFM welcomed the Minister's acknowledgment of State complicity, and suggested that it provided the basis for moving towards the establishment of a distinct redress scheme for Magdalene survivors. However, the group insisted that it was not sufficient for the Minister to admit his error. It wanted the Minister of Education to admit responsibility as well ${ }^{13}$.

By the end of June 2010, over 1,000 people had signed an online petition ${ }^{14}$ demanding "Justice for the Magdalenes". It was sponsored by JFM. It was the first

11. [http://www.magdalenelaundries.com/press/JFM\%20PR\%2015-12-09.pdf].

12. In a letter to JFM (dated 27 January 2010), Mr O'Keefe acknowledged that the Department of Justice had "confirmed that some women were referred by the Courts to the Magdalen Laundries". As such, Mr. O'Keeffe now "accept $[s]$ that this was the case as opposed to the position outlined in my letter of September last." Mr O'Keeffe repeated this new understanding in his response to two Parliamentary Questions in the Dáil on Thursday last (28 January 2010).

13. "JFM asks the Minister to make public the number of children who 'were transferred to a Magdalen laundry from a State regulated institution' as well as the number of survivors who have applied to the Redress Board on the basis of section 1(3) of the Residential Institutions Redress Act, 2002. [...] JFM demands that the Minister for Education now account for every child confined to a Magdalene laundry since the founding of the State. JFM demands that the State produce records for all women and children it was complicit in referring to the laundries. JFM urges the State to enter into dialogue with the four religious congregations involved so that they too might make available their records. Access to these records is the crucial next step in understanding this aspect of the nation's history and in establishing an appropriate redress scheme for survivors. Finally, the State should apologize to survivors for its part in the abuse of women in Ireland's Magdalene Laundries.", [http:// www.magdalenelaundries.com/press/JFM\%20PR\%2031-01-10.pdf], page viewed July 12, 2014.

14. [http://www.magdalenelaundries.com/press/JFM\%20PR\%2021-06-10.pdf], page viewed July 12, 2014. 
of its numerous direct contacts with the public, which would evolve into regular and intense social networking over the years. The group made intensive use of social networks (Facebook, Twitter and their website) to promote their activism. Finally, on the $29^{\text {th }}$ March 2011, JFM presented its "Restorative Justice and Reparation Scheme" to the government ${ }^{15}$.

In April 2011, JFM started its campaign on the human rights front, issuing a formal submission to the United Nations Committee Against Torture (UNCAT). The success that the group met in getting the support of the Irish Human Rights Commission and the conclusions of the UNCAT had a considerable influence in the subsequent events but this aspect will be developed at greater length in the third section of this paper.

The Inter-Departmental Committee on Magdalen Laundries, under the chairmanship of Dr Martin McAleese, was appointed on July 11, 2011, that is two years after JFM started its political campaign. It demonstrated the extent to which the group had been involved and the type of empowerment it was gaining.

During the inquiry, JFM remained very alert and "cautiously welcomed" the interim report published in October 2011. It also contributed to the inquiry by organizing a meeting between a group of survivors and Senator McAleese. "JFM says that the meeting was a deliberately private event, in accordance with the wishes of the women and consistent with the organisation's ethos to put the dignity and privacy of survivors first ${ }^{16}$."

The Report of the Inter-Departmental Committee to Establish the facts of State involvement with the Magdalene Laundries was published on February 5 , $2012^{17}$. JFM was satisfied with the general line of the Report:

Justice for Magdalenes welcomes both Senator Martin McAleese's central findings that the State was directly and fundamentally involved in the Magdalene Laundry Institutions and also his wish that his Report brings "healing and peace of mind to all concerned, most especially the women whose lived experience of the Magdalene Laundries had a profound and enduring negative effect on their lives ${ }^{18}$.

However, the group noted that some aspects of the inquiry needed further clarification and asked for an official apology as well as provisions for a redress and compensation scheme for survivors ${ }^{19}$. An Taoiseach Enda Kenny delivered the

15. [http://www.magdalenelaundries.com/JFM_2011_Restorative_Justice_Reparations_Scheme.pdf], page viewed July 12, 2014, page viewed July 12, 2014.

16. [http://www.magdalenelaundries.com/press/JFM\%20PR\%2007-06-12.pdf], page viewed July 12, 2014.

17. [http://www.justice.ie/en/JELR/Pages/MagdalenRpt2013], page viewed July 12, 2014.

18. [http://www.magdalenelaundries.com/press/JFM\%20PR\%2005-02-13.pdf], page viewed July 12, 2014.

19. "JFM is calling on the government to issue an immediate apology to all survivors of the Magdalene Laundries on Tuesday. Moreover, we are calling on the government to establish a transparent and non-adversarial 
public apology on February $19^{20}$. One month later, JFM published The Survivor Guide to Magdalen Restorative Justice Scheme ${ }^{21}$ and eventually announced that it was ending its political campaign on May 17, 2013.

This brief and by no means complete or detailed chronology of the political campaign led by JFM demonstrates that the group was very active and managed, in the span of a little more than four years, to move the issue of the Magdalene Laundries from a non-issue, or a media frenzy essentially focused on laying the blame on religious orders, to a political issue, and obtain what had seemed unconceivable at the beginning of the $21^{\text {st }}$ century, namely an official apology from the Irish State. After shirking its responsibilities for decades and letting the religious orders bear the full brunt of the consequences and anger of the public opinion, politicians eventually admitted that the process of institutionalization within the laundries and the inhumane treatment that some women had to go through, would not have been possible without the State's knowledge and complicity. It was the end of one the biggest political lies of $20^{\text {th }}$-century Ireland. What is more, it allowed the women who had been inmates of the laundries to be, for the first time, recognized and acknowledged as victims.

However, JFM never believed that the religious orders should be exonerated. Therefore, it focused part of its campaign on trying to encourage them to participate in and collaborate with to moving the redress scheme forward.

\section{Addressing the religious issue}

JFM met with Cardinal Sean Brady ${ }^{22}$ in June 2010. He characterized their presentation of the facts as "fair and balanced". And, as reported by The Irish Times, he encouraged JFM to "continue its efforts to establish dialogue and a process of justice and healing for all concerned ${ }^{23}$ ". On the Cardinal's recommendation, JFM wrote to Sr. Marianne O'Connor, CORI's Director General, on 9 July 2010 and requested the opportunity to present its campaign. On 1st October 2010, Sr. O'Connor informed JFM that CORI would not meet with the group ${ }^{24}$. JFM

compensation process, that includes the provision of pensions, lost wages, health and housing services, as well as redress, and that is open to all survivors, putting their welfare at the forefront. Magdalene survivors have waited too long for justice and this should not be now burdened with either a complicated legal process or a closed-door policy of compensation ", Ibid.

20. [http://www.breakingnews.ie/ireland/full-text-of-enda-kennys-apology-to-the-magdalene-laundries-survivors-585372. html], page viewed July 12, 2014.

21. [http://www.magdalenelaundries.com/Survivor\%20Guide\%20to\%20Magdalen\%20Commission.pdf], page viewed April 19, 2014.

22. Archbishop of Armagh and Primate of All Ireland.

23. Irish Times, June 30, 2010.

24. [http://www.magdalenelaundries.com/jfm_campaign.pdf]. 
has written to the four religious congregations on four separate occasions. To-date, none of the congregations were willing to meet with the group.

However, the religious orders that ran the Magdalene Laundries participated in the inquiry chaired by Senator McAleese (the Sisters of Our Lady of Charity, the Religious Sisters Charity, the Sisters of Mercy and the Good Shepherd Sisters). An analysis of the inquiry and the report is out of the scope of the article, but the contribution and response of religious orders cannot be excluded because the inquiry could not have been initiated without the activism of JFM. It is also relevant to assess how religious orders who refused to engage with JFM agreed to collaborate with to the inquiry.

Upon the release of the Report in February 2013, they all issued statements. Although most of them apologized and expressed their deepest regrets if women who stayed in the homes did not receive proper care, some felt less compelled to be sorry and launched into historical justification. This is notably the case of The Good Shepherd Sisters, who ran four Magdalene Laundries. They explained that it was all "part of the system and the culture of the time [...] We acted in good faith providing a refuge and we sincerely regret that women could have experienced hurt and hardship during their time with us. It saddens us deeply to hear that time spent with us, often as part of a wider difficult experience, has had such a traumatic impact on the lives of these women ${ }^{25 "}$.

As for CORI, the umbrella group that bluntly refused any contact with JFM, it insisted on the equal responsibility of other actors of Irish society and the need to put the Magdalene Laundries issue into historical context: "It represents a sad, dark and complex story, especially for the women involved, many of whom were rejected, isolated and hurt by a system, which failed to respond with empathy to their various needs." CORI described the Laundries as "an inherited service and system widely used throughout Europe and elsewhere at that time". "This care system, designed essentially for women who were destitute, was basic and inadequate when viewed in the 2013 context, but in its time was provided in good faith." "The laundries were the principal means of support for the greater part of the history of the running of the refuges ${ }^{26}$."

This goes a long way towards showing to what extent religious groups and institutions are refusing to acknowledge full responsibility. The notions of "context" and "historical perspective" have been used at great length, notably in the McAleese report, by several contributors, to try and justify the psychological and at times, physical abuse, suffered by the inmates. It is an issue that deserves more

25. [http://www.thejournal.ie/magdalene-laundries-apologies-783933-Feb2013/], page viewed July 13, 2014. 26. Ibid. 
in-depth academic research. If JFM did not succeed in involving the religious orders, their appeal to human rights organisations proved far more successful.

\section{Addressing the human rights dimension}

Aside from forcing the State to admit its responsibility, it also wished to push the issue a step further, and have the Irish State condemned for disrespect of basic human rights. Two issues had to be addressed: forced and unpaid labour in the laundries on the one hand, and inhuman treatment and physical abuse on the other hand. Therefore, JFM turned to two different bodies: The Irish Human Rights Commission and UNCAT.

In June 2010, JFM submitted an enquiry application to the IHRC. The submission focused on the State's obligation to protect the women's constitutional and human rights despite the fact that the abuse took place in "private institutions". In November 2010, The IHRC's Assessment concluded that there was significant evidence that the State failed to protect women and young girls from "arbitrary detention", "forced and compulsory labour", and "servitude". The Assessment recommended "that a statutory mechanism be established to investigate the matters advanced by JFM and in appropriate cases to grant redress where warranted $^{27}$.

In June 2011, after the establishment of the Inter-Departmental Committee, the IHRC issued a statement saying that it gave "a cautious welcome to the Government decision to address the recommendations made by both the IHRC and the UN Committee Against Torture on the Magdalene Laundries". It also "welcomed the recent statement by four religious congregations on the matter". However, two years later, the IHRC was not satisfied that sufficient action had been taken and, on 18 June 2013, it published its Follow-up Report on State Involvement with Magdalene Laundries stating that:

The State failed in its obligation to protect the human rights of girls and women in Magdalen Laundries. The IHRC is calling for a comprehensive redress scheme that provides individual compensation, restitution and rehabilitation for the women in accordance with the State's human rights obligations. The IHRC also makes a number of recommendations regarding measures needed to ensure similar wrongs are not repeated in the future.

On June 26, the Government announced the establishment of a redress scheme after a three-month inquiry under the chairmanship of Justice John

27. Full statement of the IHRC: [http://www.ihrc.ie/newsevents/press/2010/11/09/ihrc-calls-on-the-government-toimmediately-establ/], page viewed on July 14, 2014. 
Quirke. A Magdalen Fund was set up, allowing for financial compensation. The religious orders who were in charge of running the institutions refused to contribute to the fund and the issue is now the object of numerous controversies.

On April 22, 2011, JFM made a formal submission to UNCAT as part of the first ever examination of Ireland ${ }^{28}$. The Committee Against Torture was "due to examine Ireland for the first time on the extent to which it is meeting its human rights obligations to prevent torture, other cruel, inhuman or degrading treatment or punishment on 23rd and 24th May 201129". The conclusions of the examination on the issue of Magdalen Laundries were damning for Ireland. Here is the full statement:

\section{Magdalene Laundries}

21. The Committee is gravely concerned at the failure by the State party to protect girls and women who were involuntarily confined between 1922 and 1996 in the Magdalene Laundries, by failing to regulate their operations and inspect them, where it is alleged that physical, emotional abuses and other ill-treatment were committed amounting to breaches of the Convention. The Committee is also expresses grave concern at the failure by the State party to institute prompt, independent and thorough investigation into the allegations of ill-treatment perpetrated on girls and women in the Magdalene Laundries. (articles 2, 12, 13, 14 and 16)

The Committee recommends that the State party should institute prompt, independent, and thorough investigations into all allegations of torture, and other cruel, inhuman or degrading treatment or punishment that were allegedly committed in the Magdalene Laundries, and, in appropriate cases, prosecute and punish the perpetrators with penalties commensurate with the gravity of the offences committed, and ensure that all victims obtain redress and have an enforceable right to compensation including the means for as full rehabilitation as possible ${ }^{30}$.

It credited the campaign achieved by JFM to a large extent and made the Irish State face its responsibilities as a member of the Convention against Torture

28. "Justice for Magdalenes (JFM), the survivor advocacy group, has made a formal submission to the United Nations Committee Against Torture. The Committee Against Torture is due to examine Ireland for the first time on the extent to which it is meeting its human rights obligations to prevent torture, other cruel, inhuman or degrading treatment or punishment on 23rd and 24th May 2011. JFM's submission draws attention to Ireland's legal duties under the Convention Against Torture to promptly and impartially investigate allegations of torture or cruel, inhuman or degrading treatment and to ensure redress for the victims of such treatment", [http://www.magdalenelaundries.com/press/JFM\%20PR\%2022-04-11.pdf], page viewed July 15, 2014.

29. [http://www.magdalenelaundries.com/press/JFM\%20PR\%2022-04-11.pdf], page viewed July 15, 2014.

30. Committee against Torture, Forty-sixth session, 9 May-3 June 2011, Consideration of reports submitted by States parties under article 19 of the Convention, Concluding observations of the Committee against Torture. 
and Other Cruel, Inhuman or Degrading Treatment or Punishment. Not only did it condemn the State for disrespect of basic human rights but also vehemently demanded punishment and redress. The wording leaves no doubt as to the seriousness of the case.

Unfortunately, the Irish Government refused to acknowledge the recommendations and JFM had to make another submission to the UN Human Rights Council, complaining that "the government communicated its acceptance of a recommendation from Thailand to institute a statutory inquiry and compensation scheme for women and children abuse victims by explaining that an apology has already been made to victims of childhood abuse and compensation awarded by the Residential Institutions Redress Board ${ }^{31}$ ", but failed to take specific action for women within the Magdalene Laundries, as recommended by the IHRC and the UNCAT. JFM made two subsequent submissions to the UNCAT before putting an end to its political campaign.

The reports given by the UNCAT revealed that the treatment of women within the laundries amounted to torture and that the Irish State had to be held accountable and set up provisions for redress and compensation. JFM relentlessly addressed the issue, making sure that the Government did not let it fall into oblivion and abided by the UNCAT and IHRC's recommendations. And it continued to do so after officially ending its political campaign.

The reason behind that decision was that the group was adamant that they had achieved the aims that they had set: an official apology and a compensation scheme.

However, they did not stop their activism and turned the group into a support and research group. It is now called JFM Research and, in March 2013, published two self-help guides, one for survivors and one for family members, available on their website. They also continue to correspond "with NGOs, academics, trade unionists and the Irish Human Rights Commission to ensure that there is appropriate follow-up on the Human Rights issues raised in this campaign ${ }^{32}$ ". Moreover, the group is still very active on social networks and has become an invaluable source of information for researchers and academics ${ }^{33}$.

The group is currently very much involved in the adoption issue and has promptly reacted to the recent events surrounding the discovery of mass graves near former Mother and Baby Homes. It has denounced the refusal by the Government to include the Magdalene Laundries in "the Commission of Inves-

31. [http://www.magdalenelaundries.com/press/JFM\%20PR\%2015-03-12.pdf], page viewed July 15, 2014.

32. [http://www.magdalenelaundries.com/press/JFM\%20PR\%2017-05-13.pdf], page viewed July 15, 2014.

33. "JFM's website will continue to be available as a source of information for survivors, relatives, researchers and all others with an interest in the history of Ireland's Magdalene institutions and the campaign for justice. JFM will also continue to operate its Facebook page for the foreseeable future", Ibid. 
tigation into Mother and Baby Homes. The Mother and Baby homes and Magdalene Laundries were both integral parts of Ireland's architecture of containment

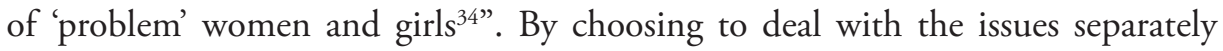
without taking into account the more global perspective and the interrelated dimension of all institutions, the Irish State is proving once more its unwillingness to admit responsibility and delaying further the compensation schemes promised by Enda Kenny in his official apology.

To this day, many former residents of Magdalene Laundries are still awaiting a full compensation scheme as recommended by Judge Quirke. Criticizing the Redress for Women Resident in Certain Institutions Bill 2014, Maeve O’Rourke of JFMR said: “This draft legislation does not meet Judge Quirke's recommendation on healthcare for Magdalene women. It is an obvious and unacceptable paring back of what the Government promised as part of the women's redress package. Judge Quirke could not have been clearer in recommending that each woman should receive a card entitling her to the full range of health services provided to state-infected Hepatitis-C survivors under the HAA card scheme. Instead, the Bill promises little more than the regular medical card, which most of the women already have ${ }^{35}$."

34. [http://www.magdalenelaundries.com/press/JFMR\%20PR\%20090115.pdf]. 35. [http://www.magdalenelaundries.com/press/JFMR\%20PR\%20190115.pdf]. 